\title{
Legitimacy, global governance and human rights institutions: Inverting the puzzle ${ }^{1}$
}

\author{
Johan Karlsson Schaffer, $\mathrm{PhD}$ \\ Norwegian Centre for Human Rights \\ University of Oslo, Norway \\ j.k.schaffer@nchr.uio.no
}

Chapter in The legitimacy of international human rights regimes: Legal, political and philosophical perspectives, edited by Andreas Føllesdal, Johan Karlsson Schaffer \& Geir Ulfstein, Cambridge: Cambridge University Press, 2013, pages 212-42.

\section{Introduction}

In this chapter, I draw on recent scholarship on the alleged legitimacy deficits in global governance institutions, seeking to engage the notions of legitimacy this literature suggests with the intriguing case of international human rights institutions. First, I reconstruct how this literature views the problem of legitimacy in global governance, a view that relies on a particular notion of international institutions which both explains and justifies global governance institutions in terms of the collective goods they help states obtain. The puzzle of legitimacy, on this view, lies

\footnotetext{
${ }^{1}$ For valuable comments on earlier versions of this chapter, I am grateful to my co-editors and the contributors to this volume; to Göran Duus-Otterström, Lennart J. Lundqvist, Marie Demker, Bengt Brülde and other participants at the Research Seminar in Practical Philosophy and Political Theory, University of Gothenburg, 8 March 2012; and to Thomas Christiano, André Nollkaemper, Michael Zürn and others who attended the MultiRights Startup Conference at the University of Oslo, 9-10 September 2011.
} 
in offering citizens valid reasons to obey, support or refrain from interfering with global governance institutions - reasons that include certain procedural, epistemic and substantive elements, which together comprise a complex, hybrid standard of legitimacy.

Second, I explore to what extent this view of legitimacy problems with global governance institutions can be applied for analyzing corresponding legitimacy problems with international human rights institutions, which constitute a different kind of political entity than typical global governance institutions. Uniquely, international human rights institutions normally do not help states obtain joint benefits in their external affairs, but regulate the internal relation between a government and individuals under its jurisdiction, and, to the extent that they are effective, chiefly rely on domestic mechanisms of enforcement. This crucial difference between the two kinds of international institutions, in turn, changes the authority relation and the legitimacy puzzle involved. In the human rights area, the problem of legitimacy is to give reasons to governments why they should accept their obligations under international human rights law, in light of the benefits or opportunities human rights treaties provide for citizens or individuals. In the third section, I draw out the implications of this analysis for finding such reasons. While the complex, hybrid standards of legitimacy suggested for global governance institutions need to be substantially reworked in order to apply to international human rights institutions, the often discarded notion of state consent provides an essential component of legitimacy for the human rights area. Finally, I discuss whether the notion of international institutions discussed in the chapter may have implications beyond the human rights area.

\section{Global governance institutions and problems of legitimacy}

Over the past couple of decades, scholars from various fields - international law, political philosophy, international relations, European studies, etc - have produced a burgeoning literature on the legitimacy of the institutions of global governance. Most, if not all, seem to agree that there is an expanding gap between, on the one hand, the number, the scope and the power of 
international institutions, and, on the other hand, the justification of their right to govern, which cannot merely, or at all, be based on the consent of the states that have created them and delegated authority to them. And while some doubt that this gap could be overcome, most seem to think of it as one of the most urgent contemporary global political matters. In short, a broad international academic literature seems to agree that we are witnessing an impending legitimacy crisis in global governance (Clark 2004; Zürn 2004; Scholte 2004; Keohane 2003; Zürn \& Stephen 2010).

In this chapter, I shall draw on a particular line of scholarship that has addressed problems of legitimacy in global governance. I shall refer to it as cosmopolitan functionalism, for it combines an attempt to explain and justify international institutions in terms of the benefits they help states obtain - a functionalist argument - with a commitment to liberal cosmopolitanism; the idea that human beings are equally the ultimate units of moral concern for everyone (and that states, consequently, are at most of derivative value). As another characteristic trait, cosmopolitan functionalism rejects state consent, global democracy and global justice as normative conceptions of international institutional legitimacy, and instead suggests that a proper theory of legitimacy for global governance must be complex, taking into account both procedural, epistemic and substantive elements. Admittedly, I take certain liberties here, since the theorists whose arguments I group together under this label may perhaps not think of themselves as members of the same family, nor be comfortable with the label, and their accounts of legitimacy differ in some respects.

In general, however, cosmopolitanism and functionalism are not improbable allies. For instance, recently burgeoning literatures on political cosmopolitanism and global justice (e.g. Held 2006; Kuper 2006; Pogge 2002) often rely on functionalism in order to justify a cosmopolitan political order: Many pressing contemporary societal problems transcend the borders of stats and therefore call for corresponding cross-border, functional, multi-level and multi-sited governance institutions, rather than the current order of sovereign states or a rigid world state, in order to approximate cosmopolitan ideals (Karlsson 2008, chap.5). 
The object of study for the literature on legitimacy in global governance is increasingly influential international organizations, such as the International Monetary Fund, the World Trade Organization, the International Criminal Court, or the United Nations and its various organs and agencies. A key reason for focusing on such institutions is the political power or authority they exercise, but it is a type of authority that distinguishes them from other political entities, most notably states, and may therefore require evaluation according to different notions of justification and legitimacy. Akin to states, global governance institutions issue rules and claim the authority to sanction those who fail to comply with those rules (Buchanan \& Keohane 2006). By the rules they set, institutions may constrain the choices facing societies and impact on many persons' fundamental interests, which makes them distinctly political institutions (Caney 2009). In contrast to states, however, global governance institutions have a restricted remit rather than comprehensive authority; they do not claim a Weberian monopoly of violence, and they rely for their implementation chiefly on the consent of states that delegate authority to them (Buchanan \& Keohane 2006). Moreover, compared to a state, a global governance institution usually by definition faces greater cultural pluralism and people do not identify with it in the way that they identify with their states and nations. To conclude, global governance institutions are sui generis, which sets the terms for assessing them normatively (Caney 2009, p.111).

What justifies the existence of such institutions? From a cosmopolitan functionalist perspective, we may think of three kinds of instrumental justifications for international institutions: They provide joint benefits, prevent abuses of power and promote global justice. The first set of arguments, which reflects neoliberal institutionalist theories of international cooperation, focuses on the short-term and fairly concrete benefits international institutions provide by helping states overcome collective action and coordination problems that result from the anarchical condition of the international system. Institutions enable states, as self-interested as they are, to construct regulatory frameworks and establish mutually beneficial welfare-enhancing cooperation that they cannot otherwise obtain. Typical examples of such cooperation are regulatory regimes that promote free trade, regulate financial markets, or curb border-transgressing envi- 
ronmental degradation. Another set of arguments, drawing, perhaps, on federal-republican international theory, suggests that in an international system characterized by immense power asymmetries, international institutions play an important constraining role, as a system of checks and balances on sovereign states, preventing powerful states from abusing their power and protecting weak powers from domination (Deudney 2007; Ikenberry 2001). In that sense, international institutions, built on strategic restraint, by which the great powers make concessions to smaller states in exchange of compliance, may advance a nascent liberal, constitutional order. A third set of arguments, which mirrors more idealist notions assuming international cooperation to serve a harmony of interests, suggests that global governance institutions serve a greater purpose of the common good, such as promoting world peace or global justice. Eventually, global governance institutions will play an important part in a functional division of labour in the pursuit of global justice or in developing a cosmopolitan political order, and they may help to ensure that otherwise unwilling states comply with cosmopolitan aims and principles. That is, not only would multilateral institutions ameliorate an anarchic system of sovereign states; institutions may potentially, in the long run, lead the international order to transform into something qualitatively different (Jacobson 2000) - possibly some sort of cosmopolitan world order.

While not necessarily mutually coherent (nor exhaustive), these three sets of arguments joint benefits, checks and balances, and global justice - supposedly answer the question why international institutions exist in two related but distinct ways. First, they offer normative justifications of international institutional authority: Global governance institutions may hold a prima facie presumption of normative justification to the extent that they fulfill certain functions and promote certain ends. Hence, these justifications are instrumental or functional, as they do not seek to justify international institutions in terms of some innate virtue or inherently fair procedures, but in terms of the outcomes they help bring about. Such instrumentalism may seem the obvious way to justify international institutions, but one may think of corresponding justificatory theories of the state to see why instrumentalism does not exhaust the possibilities (cf. Zürn \& 
Stephen 2010). Second, these arguments may also read as functional explanations of why international institutions exist: The agents of world politics create international institutions in order to solve collaboration and coordination problems in the provision of certain collective goods, such as a clean environment, world peace or international order. As explanatory accounts of international institutions, then, these arguments seem consistent with a rationalist-functionalist account of international institutions. The justificatory aspect dovetails with the explanatory aspect, showing to the potential skeptic why international institutions in general are both desirable and feasible.

However, while the provision of such public goods may justify the existence of global governance institutions, it does not obviously legitimate their authority. To the extent that one explains or justifies international institutions in terms of the collective goods they provide, one also needs to clarify who constitutes the collective that may enjoy the good: Cui bono? While some of these collective goods are pure public goods - in the sense that anyone, and not just the contracting states, could enjoy world peace - others are less purely public, as the contracting states are the primary or only direct beneficiaries, and may not automatically translate into a collective good for the populations of those states. Moreover, even if a good or service is strictly and wholly public in consumption, it remains private in production; even when everyone can enjoy the good, someone must pay the price of providing it (Filippov et al. 2004, p.51). David Lake, who theorizes international authority defined in terms of a social contract, points out the distributional effects of creating an authoritative institutional order:

'As a negotiated compact, authority must benefit on average the members of the relevant society. ... But even if everyone in society benefits from having a social order in general, some always benefit more than others. These beneficiaries, in turn, have incentives to support the creation of particular authorities in the first place, and, once vested in that authority, have especially strong reasons for supporting the governor and its corresponding political order." (Lake 2010, p.593) 
Thus, any authoritative institutional order may have profound influences on the distribution of social, economic and political success and failure within a community (cf. Bohman 1999) and what is to agree upon for governments representing states (even if they were somehow perfectly representative of their respective citizens' interest) is not the same as what is rational if the interest of each and every citizen were directly taken into account (Kuper 2006, p.16f). For our present purposes, distinguishing between beneficiaries and benefactors is important in order to understand why the authority exercised by global governance institutions, in spite of the benefits that explain and justify their existence, may open for important legitimacy problems.

Secondly, while we may quite convincingly justify international institutions generally in terms of the public goods they provide to governments, to states and their citizens, or to humanity as a whole, such arguments seem insufficient to ground the legitimate exercise of authority by particular international institution over its particular subjects. In fact, it is not obvious that the mere unsolicited provision of benefits would ground any right to rule at all (A. J. Simmons 1999). Thus, like firms and states global governance institutions solve certain problems of collective action, and their existence may therefore be desirable and justified, compared to anarchy, but they do not acquire any right to rule over unwilling persons simply by virtue of being useful.

\subsection{International institutional legitimacy: Problems and solutions}

Having thus reconstructed a cosmopolitan functionalist account of what global governance institutions are (as distinct from other types of political institutions) and why they are justified in general, let us proceed to discuss the ways in which they give rise to legitimacy problems. Global governance institutions may be a good thing to have in the world in virtue of promoting joint benefits, checks and balances, and global justice, but in order for such institutions to provide those goods efficiently, people must perceive the institutions to be legitimate. As Buchanan $\&$ Keohane (2006; cf. 2011) put it, '[t]he perception of legitimacy matters, because, in a democratic era, multilateral institutions will only thrive if they are viewed as legitimate by democratic 
publics." However, in recent years, people - typically, citizens of Western, liberal democracies or an emerging transnational civil society - have increasingly started to question and dispute the authority exercised by international institutions, a development which may portend an impending crisis of legitimacy (cf. Clark 2004; Zürn et al. 2012), most theatrically indicated, perhaps, by violent protests at various international summits. In terms of descriptive or subjective legitimacy, many people increasingly seem to believe that these institutions, or the broader political order that they comprise, do not live up to their normative expectations of a decent political order, and, as people act on such beliefs, international institutions will increasingly have difficulties to provide the public goods that justify their existence (Zürn 2004). Further, these beliefs about a lack of legitimacy may be correct. In normative or objective terms, international institutions fail to meet the appropriate standards of legitimacy, but people's subjective beliefs about the illegitimacy of an institution may also have normative implications: Whether an institution has the objective right to exercise power may depend in part on whether people subject to its authority it find it legitimate.

Thus, we could say that following this view, and admittedly much simplified, the problem of legitimacy in global governance involves three sets of entities: International institutions, governments (and their various agencies), and citizens. We may call this the authority relationship, which is the object of legitimacy - the circumstance that may need normative legitimation and social acceptance (cf. Lake 2010). For governments, who on average are the primary beneficiaries of the collective goods an institution provides, to be able to obtain those goods may seem sufficient justification, in line with their rational self-interest. Legitimacy crises arise when citizens distrust international institutions to the extent that they can no longer provide the collective goods for which they were set up. The puzzle lies in offering individuals reasons, short of justice and self-interest (Buchanan \& Keohane 2006), to accept the authority of international institutions even though they are far from just and even though individuals are not necessarily their net beneficiaries. And the fact that institutions provide one class of agents (governments or states) with certain joint gains may seem an insufficient reason for another class of agents (citi- 
zens) to accept the authority of that institution, and to bear the costs, directly or indirectly, of providing those benefits (Peter 2010; Waldron 1987). Of course, this is not to deny that global governance institutions may imply benefits or opportunities for individuals, or imply costs or constraints for states. Governments of developing countries finding may, for instance, find international economic multilaterals such the International Monetary Fund or the World Trade Organization to be to their net disadvantage, and yet find no other option but to participate. But the legitimacy crisis of global governance typically arises when governments need to convince citizens that they should carry the burdens of having their state participate in such institutions, even if it is not to their direct advantage. In such situations, citizens may plausibly find the standard justification of global governance institutions - the promotion of certain otherwise unobtainable public goods - an insufficiently legitimating reason.

The question then is: Under what circumstances should citizens obey, support or at least abstain from interfering with international institutions? In other words, what criteria should international institutions fulfill in order to be legitimate? Cosmopolitan functionalist contributions to the literature on legitimacy in global governance tend to share a few commonalities: Rejecting theories that point to global democracy, global justice or state consent as conditions of legitimacy, they instead present theories of normative legitimacy which bring in a diverse set of elements into complex or hybrid standards or principles according to which international institutional legitimacy can be objectively assessed. Thus, for instance, Allen Buchanan \& Robert Keohane (2006) present a complex standard of legitimacy, whereby a global governance institution is legitimate - and thus deserves that those who are subject to it treat the rules that it issues as worthy of compliance, regardless of the content of those rules - to the extent that it (a) enjoys the on-going consent of democratic states; (b) meets certain substantive criteria, such as not violating basic human rights and actually meeting the objectives in terms of which it justifies its existence; and (c) provides outside epistemic agents, such as NGOs, opportunities to engage in 
monitoring what it does and to participate in revising its goals and procedures. ${ }^{2}$ Simon Caney (2009) offers a shorter but similar hybrid model, which combines a substantive and a procedural component: “international institutions should be designed so that (i) persons' most fundamental rights are upheld ... and, then, (ii) over and above that they provide a fair political framework in which to determine which principles of justice should be adopted to regulate the global economy" (he focuses on institutions of economic governance). Based on the hybrid model, he suggests reforms to global governance which focus on improving participation, representation, transparency, accountability and public justification. ${ }^{3}$ Finally, Matthias Kumm (2004) presents a constitutionalist model for analyzing the legitimacy of international law as a form of global governance. He suggests that while international law has a prima facie justification in virtue of the public goods it promotes, that formal principle of legality must be weighed against a jurisdictional principle of subsidiarity, a procedural principle of adequate participation and accountability, and a substantive principle of achieving outcomes that do not violate fundamental rights and are reasonable.

There are certain important differences between these authors in how they conceive of normative legitimacy. Buchanan \& Keohane define legitimacy as a right to rule, but in their conception that right is not limited to a right to coercively enforce rules against non-compliers;

\footnotetext{
${ }^{2}$ More recently, Buchanan \& Keohane (2011) exclude the element of democratic state consent from their complex standard of legitimacy.

${ }^{3}$ While Caney does not explicitly reject Buchanan \& Keohane's complex standard, he does criticize a modified version of state contractarianism ("SCIII") that incorporates elements similar to their procedural, substantive and epistemic elements. Against SCIII, Caney (2009, p.109) argues that while incorporating a democracy criterion of membership may contribute to the legitimacy of an international institution vis-à-vis the citizens of democratic member states, it fails to legitimate the institution's inescapable coercive impact on members of non-democratic states (a point also acknowledged by Buchanan \& Keohane).
} 
rather, in their wide definition, ruling 'includes promulgating rules and attempting to secure compliance with them by attaching costs to non-compliance and/or benefits to compliance." Neither does the right to rule correspond to a duty to comply on the part of subjects; legitimacy establishes content-independent reasons for governments to comply with the regulations of a global governance institution and, for citizens, to support it, or at least not to interfere with or seek to overthrow it. A conception of legitimacy that includes a duty to obey and a right to coerce, they suggest, is 'too strong for global governance institutions, which generally do not wield coercive power or claim such strong authority' (Buchanan \& Keohane 2006, note.11; cf. Buchanan 2010, p.81ff). In some cases, of course, an international institution may claim authority in a stronger sense (a right to rule exclusively, to be obeyed and to coerce noncompliers), but, they claim, we can still ask whether a global governance institution that only claims weaker forms of authority is legitimate and whether, for instance, citizens, who are not subjects of the institution's attempt to impose duties, have content-independent reasons for supporting the institution.

Kumm, by contrast, asserts that legitimacy entails a duty to obey, suggesting that:

'the very idea of legitimacy develops clearer contours when connected to questions of obedience. Only if and to the extent that international law is legitimate is there a moral duty to obey international law. Such a duty, to the extent that it exists, is of central concern for citizens governing themselves through the framework of a national constitution.' (Kumm 2004, p.908)

However, Kumm says less on whether legitimacy also entails a right to rule and to sanction noncompliers, and if so, what institutional agent has that right. Indeed, part of the problem of legitimacy, on his view, is the lack at the international level of authoritative institutions comparable to the legislative bodies at the state level. It is part of his description of international law as governance that international treaty-bodies may increasingly have the authority to specify state obligations, which may in turn constrain the choices available to the democratic citizenry. Fur- 
thermore, the international legal order "exerts influence" on domestic processes and "exerts pressure" on non-compliers. It is unclear, however, whether such authority also entails a right to enforce, to coerce. Like Buchanan \& Keohane, then, Kumm seems to understand authority chiefly as a form of coordination, by which power is exercised via incentive structures and normative frameworks, rather than via coercive force.

While such softer notions of authority may seem to fit the current structure of global governance, they may cause two problems for the argument. First, they may appear to imply that we contrast the flat, networked nature of global governance with a caricatured notion of the state, but the enforcement repertoire of modern states is hardly limited to physical coercion. Beyond the simple dichotomy of coercion and coordination and beyond the ideal-types of 'the state' and international institutions, the difference in hierarchy between the domestic and the international sphere may be conceived as a matter of degree, where the extremes are seldom approximated (Lake 2009). Second, conceiving of authority as coordination may also seem to downplay the problem of legitimacy and to depoliticize the power exercised by global governance institutions. Even when institutions govern via incentive structures and normative frameworks, rather than via commands and coercion, they may significantly constrain the freedom of the agents over which they exercise authority (cf. von Bogdandy et al. 2008).

Caney (2009) rather emphasizes the political power that international institutions exercise, which helps him to dismiss varieties of state consent as morally inadequate notions of legitimacy. The tremendous regulatory, coercive impact these institutions have over states, and thereby over people's lives and choices, make them explicitly political, he argues. Caney descriptively asserts international institutions' de facto power, which he defines in general Dahlian terms as influence (Lukes 1974). Insofar as such institutional power fulfills the criteria of normative legitimacy, I think we might understand it as a right to rule, to be obeyed and to coerce noncompliers: International institutions issue binding rules and have coercive impact, on Caney's view, which is why he thinks they need legitimation. Hence, although Caney does not explicitly 
relate legitimacy to authority, his view comes closest to include all three elements of a strong notion of legitimacy.

Yet, these conceptions of international institutional legitimacy share certain commonalities. They suggest that legitimacy results from fulfilling not a single value or property, but a mixture of procedural, epistemic and substantive components. While the conceptions may differ in their weighting of these elements, their common key substantive concern is that an international institution cannot be legitimate if it violates basic human rights, assuming that such rights provide a standard for minimal moral acceptability to which most people would agree, while the procedural components call for channels through which a select group of actors - democratic states and non-governmental organizations - can express their consent, monitor and hold to account. In that sense, they reflect a nuanced, pluralist idea of what may contribute to enhance the legitimacy of global institutions and avert potential crises of legitimacy.

Now, what are we supposed to do with these standards? One might understand them as operationalizations of normative concepts of legitimacy for empirical research. Hence, we could, presumably, apply the standards to real existing international institutions in order to compare their legitimacy, perhaps quantifying and ranking them according to a legitimacy index. We would face certain epistemic problems of reliability and validity, such as how to weight the various components and how to quantify from qualitative observations. For instance, when assessing whether an institution fulfills the criterion of ongoing consent of democratic states, should the consent of India and Iceland count the same, or rather in proportion to their population? And where along the continuum between a simple majority and full consensus would the criterion be fulfilled? Determining such issues is difficult, but manageable, as for any empirical study of the kind (cf. Buchanan \& Keohane 2011). Such an index might be useful, for instance for testing whether international institutions that score high on the normative legitimacy index, or on its various components, also meet higher social acceptability among states or other key groups. 
However, another way to understand these normative standards of legitimacy rather sees them as providing guidance for political action. As individuals, policy-makers or citizens, we ought to take these principles to heart and act on them by giving our support to institutions that fulfill the standards, while working to reform those that fall short. Understood in this way, the complex, hybrid standards are part of a theory about the conditions under which citizens of Western, liberal democracies have a moral duty to obey international law in their exercise of constitutional government (to speak with Kumm) or have content-independent reasons to support or at least not interfere with global governance institutions (on Buchanan \& Keohane's view), or the standard may indicate principles that citizens or policy-makers of such states should adhere to when designing or reforming international institutions in order to improve their legitimacy (which seems to be Caney's intention). ${ }^{4}$ I take it that these authors conceive of their standards as guiding action and policy in this sense, or perhaps they would dispute the distinction between a standard for empirical research and one for political action (on action-guidance, see Sangiovanni 2009). However, if we take the standards to guide individual action, we encounter epistemic and practical problems considerably more difficult to surmount than are the difficulties of operationalizing the standards for empirical research.

First, to the extent that the standards are intended to help individual citizens or policymakers decide what to do, the more complex and unclear the standard, the more difficult it will be to act upon. For instance, judging whether an institution deserves our obedience, support or non-interference may require that we gather information about whether democratic states express consent for the institution on an ongoing basis, about the extent to which the institution impacts on fundamental human rights, is comparatively beneficial and fulfills its constitutive

\footnotetext{
4 "We advance the Complex Standard as a proposal for criteria that individuals and groups can use to determine whether particular global governance institutions ought to be regarded as authoritative in their domains of operation. ... as a reasonable basis for a valuable practice." (Buchanan \& Keohane 2011, p.45)
} 
purposes, and about whether the institution allows external agents to participate in revising its objectives and procedures. While such epistemic problems in assessing the standard may be manageable within a scientific study, many individuals will find it difficult to gather and assess such information, even when the institution readily provides it to outsiders (a criterion included in Buchanan \& Keohane's standard). Such epistemic difficulties may not seem to undermine the normative validity of a conception of legitimacy, but they reduce its potential to guide political action. We cannot expect individuals to act on principles that they find unintelligible, opaque or equivocal, especially not as a requirement of legitimacy (Waldron 1987).

Second, even if citizens could reliably gain the knowledge about international institutions they would need, how are they supposed to act upon that knowledge so as to conform to the demands of legitimacy? Put differently, what does it mean for citizens, in Kumm's words, to obey or disobey international law when they collectively exercise constitutional government or design domestic political and legal institutions? What does it require for citizens to act on their content-independent reasons, on Buchanan \& Keohane's view, to support or at least not interfere with or overthrow legitimate global governance institutions? Citizens in modern, democratic states mainly participate in constitutional government by electing representatives. It seems hard to tell what it means for citizens to obey international law or to support international institutions when they cast their vote for a party or a candidate (or occasionally a referendum proposal). Any person's individual impact on global governance is so attenuated, and may be offset by a range of other pertinent, salient concerns, so as to be practically meaningless, most of the time. ${ }^{5}$ Moreover, it seems close to a category mistake to require of citizens that they obey international law in their exercise of their democratic rights, since they are rarely subjects of international authority in the way that the states they inhabit and the governments they elect may be, even taking into account the blurring of the distinction between national and international law described by Kumm. As an official or agency of the international law system (cf. Waldron 
2011), a government (and, in turn, its officials and agencies) seems a more plausible candidate for holding a duty to obey international law in its collective exercise of constitutional government, and it is also more likely than citizens to have the epistemic capacity to exercise such a duty in a meaningful way.

A third problem with these complex standards is whether the components they embody really are of the kind that would grant an institution the right to rule and to be obeyed by those subject to its authority. Take Buchanan \& Keohane's standard as an example: The fact that an institution receives the ongoing consent of democracies, meets its own objectives and refrains from violating basic human rights, and allows outside agents to monitor and to hold it to account may show - to paraphrase A. John Simmons - that it is good (or, at least, not bad) in certain ways, but it does not obviously show that it has the kind of special moral relationship with any particular subjects that gives it a right to rule over them, to be obeyed by them and to sanction non-compliers (A. J. Simmons 1999, p.748). Of course, Buchanan \& Keohane do not actually suggest that individuals have a duty to obey the directives of an institution that appropriately fulfills their standard, only that they have reason to refrain from interfering with, or even positively support, such institutions - to reform them, and not overthrow them (Buchanan \& Keohane 2011, p.43). But this more modest demand on individuals indicates that their standard actually is not so much part of a theory of the legitimacy of international institutions, but of their justification. Similarly, Caney (2009, p.118) concludes that 'international institutions possess legitimacy to the extent that they uphold fundamental rights and provide a context for the fair adjudication of competing visions of how to govern the global economy.' But what rights to rule (and to coerce) follow from the fact that an institution possesses legitimacy in that way? What duties to obey - or else adjust their action - fall on the agents subject to such legitimate authority? Caney indicates that legitimate international institutions would have 'the powers necessary' to uphold certain fundamental rights, which, presumably, might include rather extensive coercive means. But a theory of legitimacy may seem incomplete unless it can account for how such powers may (and may not) be wielded so as to coerce disobedient individuals. In fact, 
the cosmopolitan functionalist standards seem to elaborate further reasons in terms of which international institutions may be justified and may command a certain general respect from individuals: The criteria specify a type of institution that is morally acceptable, seeking to convince the hypothetical anarchist that having institutions of this type, as flawed as they may be in practice, is preferable to the status quo ante (Buchanan \& Keohane 2011, p.49). But such justificatory arguments in fact say little about the grounds of legitimate authority: The right of an institution to rule over and to be obeyed by its subjects and to coerce those who fail to comply.

Thus, taken together, for both epistemic, practical and conceptual reasons, the complex, hybrid notions of legitimacy seem inadequate as requirements on the political choices and actions of individuals or citizens. As normative demands, the standards fall short of the 'ought implies can' requirement. Of course, the standards could still fulfill other important purposes, not least by offering an operationalization of normative legitimacy for empirical research, perhaps forming part of an explanatory theory of social legitimacy, hypothesizing that the more institutions approach these objective criteria, the less societal resistance and critique they will face from the pertinent political actors. The outcome of such research, in turn, may inform public debates about international institutions, and so influence indirectly the choices of citizens (a reasonable interpretation of Buchanan \& Keohane's view).

Still, while these standards may be difficult to act upon, the important point is that taking them to guide action for citizens, rather than just to operationalize a normative concept of legitimacy for empirical research, also clarifies how this literature understands the legitimacy problem of global governance institutions: The problem entails giving citizens reasons to accept the authority of international institutions, even though the benefits such institutions provide are mainly enjoyed by states. In order to solve this impending legitimacy crisis, cosmopolitan functionalism suggests combining procedural, epistemic and substantive elements into a complex, hybrid standard of legitimacy, which may then be used to assess whether citizens should obey, support or abstain from interfering with institutions that live up to such complex measures. Now, in the next section, I shall explore how we need to modify this understanding of international 
institutions, and of the problems and solutions of their legitimacy, in order to make sense of the peculiar case of international human rights institutions.

\section{Why international human rights treaties are different}

Now, could we apply or transpose the notions of legitimacy in global governance to the case of international human rights institutions? I shall suggest that the peculiar nature of international human rights institutions recasts the problem of legitimacy in ways that have important repercussions for how to assess and address their legitimacy in normative terms. Detailing how international human rights institution differ from other international regulatory regimes or global governance institutions will help us understand better the problem of their legitimacy, which in turn will help us better grasp solutions to that problem. Thus, this section serves to present an idea about how international human rights institutions have an impact on politics, what sort of difference they make, and what kind of authority they hold over whom. That idea will then serve as the basis for an argument about how to understand the problem of their legitimacy. Moreover, this exercise may also help us determine the proper scope of cosmopolitan functionalism as a general approach to international institutional legitimacy.

What is so special about international human rights treaties? A number of international relations scholars have noted how international human rights regimes present something of an anomaly for mainstream theories of international relations. Some scholars have sought to analyze international human rights regimes as yet another case of global governance - a regime similar in kind to those regulating other issues areas (Donnelly 1986; Nickel 2002; Montgomery 1999). However, international human rights law and the mechanisms for its enforcement diverge in important respects from most forms of international institutions that seek to regulate interactions among states, as Andrew Moravcsik points out: 
'Unlike international institutions governing trade, monetary, environmental, or security policy, international human rights institutions are not designed primarily to regulate policy externalities arising from societal interactions across borders, but to hold governments accountable for purely internal activities. In contrast to most international regimes, moreover, human rights regimes are not generally enforced by interstate action. Although most arrangements formally empower governments to challenge one another, such challenges almost never occur. The distinctiveness of such regimes lies instead in their empowerment of individual citizens to bring suit to challenge the domestic activities of their own government.' (Moravcsik 2000)

Hence, international human rights regimes constitute a special case of international institutions because they constrain government behaviour towards citizens, rather than inter-state behaviour. Furthermore, unlike other regimes, international human rights regimes do not necessarily represent any mutual gain for contracting states (Landman 2005).

Conventional approaches to international politics seem to have difficulties making sense of these peculiar aspects of international human rights regimes. Beth Simmons (2009, p.114) suggests that international relations scholars have been overly pessimistic about the political impact for international human rights treaties because they have been looking in the wrong direction: 'outward at interstate relations rather than inward at state-society relations.' Evaluating existing accounts that seek to explain states' compliance with international human rights treaties as a matter of inter-state politics, Simmons argues that the realist skeptics are mostly correct and that rationalist-functionalist theories largely miss the mark. Realists are accurate in their claim that governments are unlikely to comply with international human rights treaties unless it is in their interest to do so. Moreover, the family of rationalist-functionalist theories, analyzing international institutions in terms of self-enforcing agreements and credible commitment, 'is simply an uncomfortable fit for explaining human rights compliance' (B. Simmons 2009, p.123). Simmons indicates at least three ways in which such theories have difficulties explaining why states 
comply with international human rights treaties: In the human rights area, there are no joint benefits, since a state can generally realize the level of rights protection it desires without the cooperation of other states, there is no reciprocal enforcement, as a government is unlikely to alter its own rights practices in order to reciprocate for abuses elsewhere, and there are no significant reputational costs, since, compared to other areas, it is hard to identify consequences of a bad reputation with respect to human rights treaty compliance. ${ }^{6}$ Similarly analyzing the limits of international action as a mechanism of human rights enforcement, Jack Donnelly (2002, p.178f) suggests that other states are unlikely to find it in their self-interest to reciprocate or retaliate abuses by a government against the human rights of its own citizens. Retaliatory interstate action is costly, because leverage must be imported from other areas, such as trade or aid; difficult to legitimize, since such means of retaliation are only indirectly tied to the violations; and risky, since it is so much easier to produce great harm than great benefit through international interventions and sanctions. Thus, because of their peculiar nature, international human rights treaties give rise to, rather than help solving, problems of collective action among states.

And yet, international human rights treaties do have a political impact - it just occurs in another political domain than where students of international relations and international law have been prone to look: In the domestic realm. Scholars providing such second-image explanations argue that international human rights treaties can have important effects on domestic politics, by empowering individuals and groups domestically and, correspondingly, by restricting the political discretion of governments.

\footnotetext{
${ }^{6}$ Obviously, a government may face certain costs if it builds a reputation of being a systematic human rights violator, but it is less clear that a reputation for being an unreliable treaty partner in the human rights area would make a government an unreliable trading partner or military ally, and reputational enforcement gives rise to inter-state collective action problems, so reputation works, at best, as a weak mechanism enforcing compliance (B. Simmons 2009, p.123ff).
} 
What domestic factors can account for the fact that states willingly restrict their sovereignty by binding themselves by international human rights treaties? In his case study of the European human rights system, Moravcsik (2000; cf. 1995) argues that governments commit to international human rights institutions, with independent jurisdiction and private access, just as they commit to independent domestic institutions, as 'self-interested means of 'locking in' particular preferred policies - at home and abroad - in the face of political uncertainty.' This tactic is particularly useful for newly established democracies, for which the benefits of stabilizing the domestic political status quo against anti-democratic threats outweigh the sovereignty costs of membership. Hence, by alienating sovereignty to an independent international authority and binding itself to an international human rights treaty, a government may seek to preserve its favored domestic policies and insulate itself from the actions of future governments. Relatedly, Simmons (2009) proposes that governments primarily commit to international human rights treaties because they believe that they can and will live up to the treaty's provisions. Of course, some governments may ratify insincerely, for strategic reasons or because of peer pressure, whereas other governments who share the treaty's values still fail to ratify because domestic legal traditions, ratification procedures or decentralization influence the treaty-acceptance process. At any rate, once governments have publicly committed to a treaty, it also constrains them by focusing expectations on certain accepted and proscribed behaviours.

International human rights treaties not only serve to constrain domestic governmental discretion, however, but also provide opportunities for political action, by allowing individuals and groups new means by which to pursue their interests vis-à-vis their governments. In order to explain why states comply with international human rights norms, Simmons (2009) suggests three mechanisms by which international human rights treaties may have an impact on domestic policies and in turn on human rights practices: Treaties may effect elite-initiated agendas, by raising questions of ratification and implementation, and thus insert topics into domestic politics that would not otherwise have been there. Further, treaties may support litigation, by rights claimants and lawyers, especially where treaties have the status of domestic law and where 
courts are relatively independent from political power. Finally, treaties may spark mobilization by providing crucial political, legal and social resources to individuals and groups whose goal is to hold governments to their promises. Whether such mechanisms are effective depends crucially on the institutional features of the domestic political and legal system, and on the nature of the human right in question, and changes are often subtle: 'They involve changes that give relatively weak political actors important tangible and intangible resources that raise the political costs governments pay for foot-dragging or for noncompliance' (B. Simmons 2009, p.15).

Summarising her argument, Simmons suggests that international human rights treaties constitute a unique class of international agreements:

'International human rights treaties have a singularly unusual property: They are negotiated internationally but create stakeholders almost exclusively domestically. In the human rights area, intergovernmental agreements are designed to give individuals rights largely to be guaranteed and respected by their governments. Treaties of this kind have a potentially dramatic impact on the relationship between citizens and their own government, creating a huge pool of potential beneficiaries if the treaty is given effect. ... By sharp contrast, international human rights treaties engage practically no important interests among states in their mutual relationships with each other. Most of these agreements simply do not have the capacity to alter international politics in important and predictable ways. The same is not true of politics at home.' (B. Simmons 2009, p.125f)

In order to see why it is not trivial to rethink international human rights regimes in this way, we may contrast it to conceptions of the practice of human rights offered in certain recent philosophical theories of human rights. Many philosophers seeking to provide a political notion of human rights (as distinct from ethical or metaphysical notions of human rights) seem to understand the international human rights regime mainly as an international agreement among liberal states, which specifies the standards that determine when the international community of states 
should accept a government of a sovereign state as a legitimate member; when other states should tolerate a government, even if it pursues certain illiberal practices; and, conversely, when external agents, individually or acting in concert, may permissibly intervene against a government that engages in gross violations of human rights (for overviews, see Baynes 2009; Nickel 2006; Tasioulas 2009; Ingram 2008; Valentini 2012). That is, these philosophical conceptions mainly regard human rights as a matter of inter-state politics, as a reason for action for governments to take into account in their exercise of foreign policy in bilateral and multilateral relations. However, they have less to say about the role international human rights norms and institutions may play in political struggles within states, where individuals and groups appropriate and apply international human rights norms, and bring them to bear on their government, seeking to improve their own situation. If this is how international human rights have their real significance, rather than serving as standards for membership and conduct in the inter-state domain, it also deserves more attention in normative philosophical accounts of international human rights (cf. Benhabib 2011). For present purposes, suffice it to say that the way we conceive of international human rights institutions generate quite different expectations about the authority relationships and the legitimacy puzzles involved.

Now, if, as a matter of empirical fact, international human rights institutions have their effects on politics not by promoting mutual benefits in inter-state politics, but by restricting governmental discretion and enabling individuals and groups to pursue their interests vis-à-vis their government, what sort of normative problems of legitimacy follow? Notably, these second-level theories are not explicitly normative, but as ontological and explanatory accounts of what international human rights institutions are and why they make a difference to politics, they describe an authority relation between states, persons and international institutions that may need a special kind of normative legitimation. 


\subsection{The legitimacy puzzle of international human rights institutions}

If legitimacy is about morally evaluating the exercise of authority, any theory of legitimacy must offer an account of who holds authority over whom, to whom justification may be owed. That is, before we can justify an institution's exercise of power, we must specify what its political significance is, and over whom. If international human rights institutions are dissimilar to global governance institutions in general, since they cannot meaningfully be construed in terms of mutual advantages and reciprocal enforcement in the external relations among states, but rather have their prime political effects in altering the internal relation between a government and its citizens, then they comprise an altogether different legitimacy puzzle as well. First, while global governance institutions may claim prima facie justification in terms of providing states with certain collective goods or joint benefits, international human rights institutions would rather claim a baseline justification in terms of providing certain advantages or opportunities to individuals and groups. Second, the provision of such advantages typically fall not on citizens, but on governments, who relinquish domestic political discretion to an independent international treaty body and commit to norms and policies that may be turned against them or their future successors.

Thus, compared to global governance institutions, international human rights institutions invert the legitimacy puzzle. In the area of human rights, the problem of legitimacy is rarely to offer citizens content-independent reasons to refrain from interfering with or actively support international human rights courts, or to show that individuals-qua-citizens have a duty to obey international human rights law when they participate in politics. Rather, the problem of legitimacy is to offer such reasons to states - to governments, parliaments, courts, the police, and other institutional agents of the state who are supposed to commit to and comply with the norms of international human rights treaties. As in global governance, there is a triangular authority relation that may need legitimation, but it points in another direction. Here, the question of legitimacy is not, as in global governance, why individuals should comply, in spite of tangible net costs, with rules or institutions which provide states with certain net benefits they could not 
otherwise obtain, but rather why governments should comply with human rights norms in spite of the tangible costs (and usually meager benefits) they impose on states, assuming that those norms hold a prima facie claim to justification in light of the advantages and opportunities they provide to individuals and groups.

Like the three sets of arguments offered to justify and explain global governance institutions, similar functional and instrumental arguments suggest themselves for human rights institutions. They may improve the human rights behaviour of states by offering alternative channels and practical tools by which individuals and groups can seek to pursue their interests, in addition to the channels and tools already offered by state and civil society institutions.

\subsection{The usefulness of state consent}

Now, if the legitimacy puzzle of international human rights institutions involves offering states or governments reasons to carry the costs or constraints they entail, the benefits or opportunities those institutions provide for individuals will seem insufficient reasons, just as joint benefits for states may seem insufficient reasons for individuals to accept the authority of global governance institutions. So in terms of what could the authority of international human rights institutions over states be legitimated? Here, I shall suggest that the legitimacy problems of international human rights institutions seem to require different standards of legitimacy than the corresponding problems of global governance institutions.

Many normative theorists of international institutional legitimacy, including those whose family resemblance I have earlier referred to by the term cosmopolitan functionalism, reject state consent: The notion that international law or institutions derive their legitimacy from the fact that states have consented to them, Buchanan \& Keohane (2006) claim, reflects an outdated, or even immoral, conception of international order that "that fails to impose even the most minimal normative requirements on states". Kumm (2004), similarly, claims that state consent today has lost its legitimating function: International treaties today increasingly delegate powers to quasi-judicial treaty-bodies, which often engage in expansive interpretation of the terms of 
their own treaties, and modern customary international law 'discounts the requirement of general and consistent state practice'. Caney (2009), likewise, argues that 'state-centric contractarianism' - the view that international institutions possess legitimacy to the extent that they have been properly authorized by states - is unable to provide an adequate account of political legitimacy.

However, given that international human rights institutions turn the problem of legitimacy on its head, might state consent in fact offer a basic component of their legitimacy? I think it does. As the puzzle now is why states (not citizens) should accept the authority of international human rights institutions, although they have little to gain from it, the fact that states actually and voluntarily have ratified human right treaties seems to provide one compelling reason (if not the only one) for why they should also comply. Applied to the peculiar case of international human rights institutions, moreover, state consent seems to withstand at least some of the standard criticism.

For instance, both Buchanan \& Keohane (2006) and Caney (2009) attempt a reductio against state consent, arguing that this notion of legitimacy presupposes that legitimacy can be delegated, so that global governance institutions inherit their legitimacy from legitimate states consenting to them. However, their objection goes, many states do not have any legitimacy to pass down the line, because they mistreat their own citizens (and foreigners) and because they lack procedures guaranteeing democratic accountability. Thus, illegitimate states cannot transfer any legitimacy to international institutions. This might seem a plausible objection, given the way we construct the legitimacy puzzle for global governance institutions. The fact than an oppressive government has consented to a global governance institution should have little significance for citizens, subjects of that government or another, who ponder whether or not to give the institution their support, let alone obey it.

But in the context of international human rights treaties, dismissing state consent on these grounds would have the equally absurd implication of absolving oppressive, non-democratic governments of their human rights obligations. Consider a state such as Eritrea, which has rati- 
fied or acceded to a range of key international human rights conventions, including the ICCPR, the ICESCR, the CRC and the ACHPR. Eritrea's government cannot claim any credentials in terms of electoral accountability, having refused to implement a democratic constitution ratified in 1997, and it persistently violates even the most basic human rights of the vast majority of its citizens (and thus also violates the terms of those treaties) by jailing political opponents, independent journalists and believers of minority religions; by systematically drafting youth to forced labour under the indefinitely extended military service; and by keeping the majority of its population just on the brink of starvation. Obviously, these established facts of oppression and tyranny cannot imply that Eritrea's government could not be held to the international human rights treaties it has ratified. But in the human rights area, the reductio objection to state consent ironically may seem to serve to relieve oppressive governments of their international human rights commitments and obligations toward their own populations: Illegitimate regimes cannot be bound by human rights conventions, since they cannot legitimately make international treaties. As that conclusion seems counterproductive, we may grant that at least in the human rights field, the fact of internal illegitimacy does not absolve a government from its international obligations.

Moreover, only some form of actual consent seems necessary to establish an authority relationship between an international human rights regime and the state governments subject to its authority. While the general virtues or benefits of having international institutions of this kind may well be taken as a reason for both individuals and governments to support them in general (or, at least, not to interfere with them), that general goodness or fairness of an institution cannot in itself ground a particular duty to comply with its directives. Put differently, a government may well accept or even support the existence of international human rights regimes, in terms of the benefits they help bring about, and yet find those general benefits to be an insufficient reason to comply with the regime in particular instances.

Of course, one might respond that the way in which the government of Eritrea treats its own citizens is plainly wrong, and that establishing the legitimate authority of the human rights 
treaties it has ratified (yet violates) adds no weight to the moral condemnation of its oppressive practices. But in the human rights field, state consent seems crucial for pragmatic reasons, offering a useful additional resource for justifying why governments should accept to be held to human rights standards: Because they have consented to them. We should not underestimate how useful state consent is in this regard. Buchanan \& Keohane suggest that "those who take human rights seriously" cannot accept "the fiction that all states - regardless of whether they respect the basic rights of their own citizens - are moral agents worthy of respect". Unpacking this double-barreled claim, one could regard states as moral agents - that is, as agents with a capacity for moral deliberation and action, who can bear the moral burdens of duty and blame (Erskine 2008) - without thinking them worthy of respect regardless of what they do, for instance, regardless of how they treat their own citizens. And even if states' moral agency might be shrugged off as a fiction (or states' corporate agency more generally, following the dominant instrumentalist methodological individualism in mainstream international theory), it might still be a fiction useful precisely to those who take human rights seriously (cf. Wendt 2004). Indeed, much of the work done by the international human rights community and transnational advocacy networks, which engage in naming and shaming of governments that fail to live up to their international human rights commitments, seems to rest on the assumption that states, or governments representing them, are moral agents, who deserve blame or praise depending on whether they respect the basic rights of their own citizens and others subject to their authority (Risse et al. 1999; Nickel 2006). Likewise, the assumption that governments could and should be held to their commitments is a key precondition for international human rights to have domestic impact - in changing elite agendas of executives and legislatures, in supporting litigation by rights claimants and lawyers, and in sparking mobilization by individuals and groups with a stake in compliance: 'Key here is the legitimating function of an explicit public commitment to a global standard. That commitment is used strategically by demandeurs to improve the rights in which they have an interest' (B. Simmons 2009, p.15). 
Hence, in the human rights area, state consent may offer a necessary component of a normative notion of legitimacy. While we might also think of other reasons suggesting why governments should comply with their human rights obligations - because it is morally right or in their self-interest to do so - such reasons are not content-independent reasons of legitimacy. Moreover, alternative components such as the ongoing consent of democratic states, proposed by Buchanan \& Keohane as a necessary element of legitimacy in global governance institutions, seems to offer little added weight in the case of international human rights institutions. Certainly, democratic governments have been the most avid supporters of international human rights treaties, ratifying optional protocols that expose them to even further scrutiny by allowing individuals to file complaints about violations to international authoritative bodies, but that enthusiasm in itself offers no additional reason why states should regard themselves as legitimately bound by those treaties, especially not for non-democratic states. Rather, one would suspect that making the legitimacy of international human rights institutions depend on the consent of democratic states would not enhance their legitimacy in many corners of the world, but rather raise fears of Western bias, parochialism and even imperialism. Additionally, for individuals and groups who seek to hold governments to their international human rights commitments, the democratic credentials of the government seems to offer little extra leverage.

And as an action-guiding notion of legitimacy, state consent offers a simpler criterion than democratic state consent, by avoiding some of the weighting and threshold problems and by being premised on the idea that sovereign states are formally equal. Moreover, state consent improves clarity: While states and other agents may often dispute the interpretation of human rights treaties, treaties have become the preferred format of international agreement precisely because they sharpen the focus on particular accepted and proscribed behaviours: 'Treaties constrain governments because they help define the size of the expectations gap when governments fail to live up to their provisions.' (B. Simmons 2009, p.14) Hence, the notion of state consent, indicated through ratification of a human rights treaty, provides a clear and therefore also feasible, action-guiding criterion of legitimacy. 
If state consent provides a necessary element of legitimacy of international human rights institutions, what else is needed? The complex, hybrid standards comprise procedural, epistemic and substantive elements that supposedly add to the legitimacy of global governance institutions. Similarly, an epistemic component may improve the acceptability of international human rights institutions to states. Allen Buchanan (2008) argues that international human rights institutions perform crucial epistemic functions that may contribute to their legitimacy, such as assessing relevant empirical information when specifying and applying human rights norms and when formulating new norms in specialized conventions. Moreover, institutions may help to resolve conflicts of interpretation, and thus help states (and groups and individuals) determine what respect for human rights requires of governments. In the particular case of international human rights institutions, such epistemic mechanisms may suggest further reasons for states to accept that form of international authority, providing a safeguard against the suspicion of parochialism and bias in the continuously developing exercise of that authority. In order to secure that function, drawing on information provided by independent experts or third parties may be useful. Hence, an epistemic element may belong on a standard of legitimacy in the human rights area, but with states as the subjects of legitimacy, it serves a different purpose than in the case of global governance institutions.

Finally, the substantive elements emphasized in cosmopolitan functionalist theories of international institutional legitimacy suggest that in order to hold legitimate authority over citizens, a global governance institution should respect generally accepted basic human rights and meet the goals in terms of which it justifies its existence. Would that element also have a place in offering states reasons to accept the authority of international human rights institutions as legitimate? The substantive elements express a concern that citizens should regard a global governance institution as legitimate only if it actually contributes to realize the sort of short and long term values in terms of which cosmopolitan functionalists may both justify and explain its existence - such as joint benefits, checks and balances and global peace or justice. Even as an institution may at times fail to fulfill those values, it should openly demonstrate that it strives 
towards the goals and have procedural mechanisms that increase the likelihood that it realizes its goals relatively efficiently and effectively, although assessing the performance of international organizations is an inherently difficult task (Gutner \& Thompson 2010). It seems uncontroversial that citizens should not accept a duty to obey, support or abstain from interfering with an institution that violates basic human rights, or that repeatedly fails to solve the inter-state problems for which it was created. In the case of human rights institutions, the two substantial elements collapse into one: Promoting the respect for human rights is the goal in which of such institutions may justify their existence.

However, if we want to pursue the inverted legitimacy puzzle, so that the subjects of legitimate authority in this case are not citizens, but governments, what sort of outcomes might constitute valid reasons for governments to regard an international human rights institution as illegitimate? The notion of minimal moral acceptability has no clear analogy in the case of human rights institutions. States sometimes justify flouting their human rights obligations in terms of threats to sovereignty (or popular sovereignty), but international human rights treaties rarely have such existential effects. Generally, international human rights law is not just consistent with but premised on state sovereignty (cf. Nagano 2006). Treaties may constrain the domestic political discretion of governments by inserting issues on elite agendas, by offering lawyers new tools, and by providing resources for social groups to mobilize, but such effects are subtle and never spell the end of sovereignty. However, if a particular international human rights institution were to persistently fail to contribute to improving the human rights situation within the contracting states generally or if it would stray too far from the core values of the treaty, such negative outcomes may provide valid reasons for states to dispute the authority of the institution.

Hence, in the human rights area, the problem of legitimacy entails defending the authority of international human rights institutions over states, in light of the benefits they provide for individuals and groups within states. If we construe the problem in this way, state consent may not only withstand some of the objections raised against it, but it may offer a necessary element of legitimacy. Of course, this is not to say that state consent is a sufficient criterion of legitima- 
cy in the human rights area, nor to suggest that it is generally a necessary condition for the legitimacy of global governance institutions, but rather that we should appreciate the usefulness of this notion of legitimacy. Moreover, if we think of states as the primary subjects of legitimacy that is, as the agents to whom legitimation is owed - in the human rights area, epistemic and substantive elements of legitimacy may well have their place, but for different reasons than in the case of global governance institutions.

\section{Conclusion}

I have emphasized that human rights institutions are inherently different than global governance institutions because they entail a different - indeed inverse - relation of authority. Turned upside down, the problem is not why citizens should accept the authority of institutions that help states obtain certain collective goods, but rather why states should accept the authority of international institutions that help individuals secure their rights and interests vis-à-vis their governments. I believe these two differently structured legitimacy problems also mirror political debates about international institutions in many countries. While some suggest that the so-called legitimacy deficit of global governance institutions is indicated by the resistance such institutions and governments face from a host of civil society groups and non-governmental organizations, such groups rarely voice resistance against international human rights treaties and their sometimes expanding authority. In the human rights area, reluctance and resistance rather comes from executives, legislatures, judiciaries, and bureaucracies - the institutional agents of the state who will have to bear the costs of implementing an international treaty with a potential to restrict their discretion and change domestic politics in subtle but unforeseeable ways.

While I have restricted my argument to international human rights treaties, as a special class of international institutions, could it be generalized beyond that case? An ontological notion of international institutions - what they are, why they come about, what their impact is and on whom - sets the terms for analyzing problems of their justification and legitimacy. And 
compared to other kinds of international institutions, international human rights institutions are sui generis: They do not entail any joint benefits among states and are not enforced through reciprocal action. They are negotiated among states, but create stakeholders in domestic societies, who can use the rights specified in international treaties as resources to hold their governments to account. Of course, this depiction of two species of international institutions is idealtypical: an abstraction, for analytical purposes, from the complexity of reality. To the extent that institutions in other issue-areas resemble international human rights institutions, the conceptions of legitimacy I have suggested here may have a more general validity. Andrew Moravcsik (2000) argues that other kinds of international agreements may be explained not just as inter-state bargains, but as independent institutional constraints governments use to increase domestic policy predictability, for instance some trade agreements. Michael Zürn (2004) suggests that new types of complex policy issues have changed the role of global governance: Whereas the institutions established after the second world war addressed states in the predictable regulation of interstate problems, new types of institutions, such as global governance regimes in the environmental area, rather target intra-state issues and rely on the compliance of domestic actors for their successful implementation. Similarly, Matthias Kumm (2004) describes how international law has expanded into what was previously considered domestic affairs, thus blurring the distinction between international and national law. Moreover, some international regimes may be of a mixed kind. For instance, international regulations on trafficking in persons both seek to address coordination and collective action problems among states and detail a set of rights for individuals to claim against those states. Such cases may seem to transcend the simple ideal-typical notions of international institutions employed here, and indicate a need for even more hybrid standards of legitimacy that are able to address such mixed authority relations. Yet, international human rights institutions uniquely empower individuals and groups to pursue their rights vis-àvis their governments, a singular feature that has important, if subtle, political effects, and which may call for a special notion of legitimacy. 


\section{Bibliography}

Baynes, K., 2009. Discourse ethics and the political conception of human rights. Ethics \& Global Politics, 2(1). Available at: http://www.ethicsandglobalpolitics.net/index.php/egp/article/view/1938.

Benhabib, S., 2011. Dignity in adversity: Human rights in troubled times, Cambridge: Polity Press.

von Bogdandy, A., Dann, P. \& Goldmann, M., 2008. Developing the Publicness of Public International Law: Towards a Legal Framework for Global Governance Activities. German Law Journal, 9(11), pp.1375-1400.

Bohman, J., 1999. International regimes and democratic governance: Political equality and influence in global institutions. International Affairs, 75(3), pp.499-513.

Buchanan, A., 2008. Human rights and the legitimacy of the international order. Legal Theory, 14(01). Available at: http://www.journals.cambridge.org/abstract_S1352325208080038 [Accessed July 29, 2011].

Buchanan, A., 2010. The legitimacy of international law. In The philosophy of international law. Oxford: Oxford University Press, pp. 79-96.

Buchanan, A. \& Keohane, R.O., 2011. Precommitment Regimes for Intervention: Supplementing the Security Council. Ethics \& International Affairs, 25(01), pp.41-63.

Buchanan, A. \& Keohane, R.O., 2006. The Legitimacy of Global Governance Institutions. Ethics \& International Affairs, 20(4), pp.405-437.

Caney, S., 2009. The responsibilities and legitimacy of economic international institutions. In L. H. Meyer, ed. Legitimacy, justice and public international law. Cambridge: Cambridge University Press.

Clark, I., 2004. Legitimacy in a global order. Review of International Studies, 29(S1), pp.75-95.

Deudney, D., 2007. Bounding power : republican security theory from the polis to the global village, Princeton: Princeton University Press. 
Donnelly, J., 1986. International Human Rights: A Regime Analysis. International Organization, 40(3), pp.599-642.

Donnelly, J., 2002. Universal human rights in theory and practice, Ithaca: Cornell University Press.

Erskine, T., 2008. Locating responsibility: The problem of moral agency in international relations. In C. Reus-Smit \& D. Snidal, eds. The Oxford Handbook of International Relations. The Oxford Handbooks of Political Science. pp. 699-707.

Filippov, M., Ordeshook, P.C. \& Shvetsova, O., 2004. Designing federalism: A theory of selfsustainabale federal institutions, Cambridge: Cambridge University Press.

Gutner, T. \& Thompson, A., 2010. The politics of IO performance: A framework. The Review of International Organizations. Available at: http://www.springerlink.com/index/10.1007/s11558-010-9096-z.

Held, D., 2006. Reframing global governance: Apocalypse soon or reform! New Political Economy, 11(2), pp.157-176.

Ikenberry, G.J., 2001. After victory : institutions, strategic restraint, and the rebuilding of order after major wars, Princeton: Princeton University Press.

Ingram, J.D., 2008. What Is a "Right to Have Rights"? Three Images of the Politics of Human Rights. American Political Science Review, 102(04), p.401.

Jacobson, H.K., 2000. International institutions and system transformation. Annual Review of Political Science, 3(1), pp.149-166.

Karlsson, J., 2008. Democrats without borders: A critique of transnational democracy. Gothenburg: University of Gothenburg. Available at: http://gupea.ub.gu.se/dspace/handle/2077/18348.

Keohane, R.O., 2003. Global governance and democratic accountability. In Taming globalization: Frontiers of governance. Cambridge: Polity, pp. 130-159.

Kumm, M., 2004. The Legitimacy of International Law: A Constitutionalist Framework of Analysis. European Journal of International Law, 15(5), pp.907-931. 
Kuper, A., 2006. Democracy beyond borders: Justice and representation in global institutions, Oxford: Oxford University Press.

Lake, D.A., 2009. Relational Authority and Legitimacy in International Relations. American Behavioral Scientist, 53(3), pp.331-353.

Lake, D.A., 2010. Rightful Rules: Authority, Order, and the Foundations of Global Governance. International Studies Quarterly, 54(3), pp.587-613.

Landman, T., 2005. The Political Science of Human Rights. British Journal of Political Science, 35(3), pp.549-572.

Lukes, S., 1974. Power: A radical view, London: MacMillan.

Montgomery, J.D., 1999. Fifty years of human rights: An emergent global regime. Policy Sciences, 32(1), pp.79-94.

Moravcsik, A., 1995. Explaining International Human Rights Regimes:: Liberal Theory and Western Europe. European Journal of International Relations, 1(2), pp.157-189.

Moravcsik, A., 2000. The origins of human rights regimes: Democratic delegation in postwar Europe. International Organization, 54(2), pp.217-252.

Nagano, T., 2006. A critique of Held's cosmopolitan democracy. Contemporary Political Theo$r y, 5(1)$, pp.33-51.

Nickel, J.W., 2006. Are human rights mainly implemented by intervention? In R. Martin \& D.

A. Reidy, eds. Rawls's law of peoples: A realistic utopia? Oxford: Blackwell, pp. 263-277.

Nickel, J.W., 2002. Is today's international human rights system a global governance regime? The Journal of Ethics, 6(4), pp.353-371.

Peter, F., 2010. Political Legitimacy E. N. Zalta, ed. Stanford Encyclopedia of Philosophy. Available at: http://plato.stanford.edu/entries/legitimacy/ [Accessed October 22, 2010].

Pogge, T.W., 2002. World poverty and human rights: Cosmopolitan responsibilities and reforms, Cambridge: Polity.

Risse, T., Ropp, S.C. \& Sikkink, K. eds., 1999. The power of human rights: International norms and domestic change, Cambridge: Cambridge University Press. 
Sangiovanni, A., 2009. Normative political theory: A flight from reality? In Political thought and international relations: Variations on a realist theme. Oxford: Oxford University Press, pp. 219-239.

Scholte, J.A., 2004. Civil society and democratically accountable global governance. Government and Opposition, 39(2), pp.211-233.

Simmons, A.J., 1999. Justification and Legitimacy. Ethics, 109(4), pp.739-771.

Simmons, B., 2009. Mobilizing for human rights : international law in domestic politics, Cambridge: Cambridge University Press.

Tasioulas, J., 2009. Are Human Rights Essentially Triggers for Intervention? Philosophy Compass, 4(6), pp.938-950.

Waldron, J., 2011. Are Sovereigns Entitled to the Benefit of the International Rule of Law? European Journal of International Law, 22(2), pp.315-343.

Waldron, J., 1987. Theoretical Foundations of Liberalism. The Philosophical Quarterly, 37(147), pp.127-150.

Valentini, L., 2012. In What Sense are Human Rights Political? A Preliminary Exploration. Political Studies, 60(1), pp.180-194.

Wendt, A., 2004. The state as a person in international theory. Review of International Studies, 30(2), pp.289-316.

Zürn, M., 2004. Global governance and legitimacy problems. Government and Opposition, 39(2), pp.260-287.

Zürn, M., Binder, M. \& Ecker-Ehrhardt, M., 2012. International authority and its politicization. International Theory, 4(01), pp.69-106.

Zürn, M. \& Stephen, M., 2010. The View of Old and New Powers on the Legitimacy of International Institutions. Politics, 30, pp.91-101. 